\title{
Classification of Proteus vulgaris biogroup 3 with recognition of Proteus hauseri sp. nov., nom. rev. and unnamed Proteus genomospecies 4, 5 and 6
}

\author{
Caroline Mohr O'Hara, ${ }^{1}$ Frances W. Brenner, ${ }^{3}$ Arnold G. Steigerwalt, ${ }^{4}$ \\ Bertha C. Hill, ${ }^{2}$ Barry Holmes, ${ }^{5}$ Patrick A. D. Grimont, ${ }^{7}$ Peter M. Hawkey, ${ }^{6}$ \\ John L. Penner, ${ }^{8}$ J. Michael Miller ${ }^{1}$ and Don J. Brenner ${ }^{4}$
}

Author for correspondence: Caroline Mohr O’Hara. Tel: +1 404639 2316. Fax: +1 4046393241. e-mail:cmo1@cdc.gov

\footnotetext{
1,2,3,4 Diagnostic

Microbiology Section ${ }^{1}$, Nosocomial Pathogens Laboratory Branch ${ }^{2}$ Hospital Infections Program, Foodborne and Diarrhoeal Diseases Branch ${ }^{3}$ and Meningitis and Special Pathogens Branch4, Division of Bacterial and Mycotic Diseases, Centers for Disease Control \& Prevention, Atlanta, Georgia 30333, USA

5 National Collection of Type Cultures, Central Public Health Laboratory, London, UK

6 University of Leeds, Leeds, UK

7 Unité des Entérobactéries, Institut Pasteur, Paris, France

8 Department of Medical Microbiology, Banting Institute, University of Toronto, Toronto, Ontario, Canada
}

Strains traditionally identified as Proteus vulgaris formed three biogroups. Biogroup 1, characterized by negative reactions for indole production, salicin fermentation and aesculin hydrolysis, is now known as Proteus penneri. Biogroup 2, characterized by positive reactions for indole, salicin and aesculin, was shown by DNA hybridization (hydroxyapatite method) to be a genetic species separate from biogroup 1 and from biogroup 3 which is positive for indole production and negative for salicin and aesculin. In this study, 52 strains were examined, of which 36 strains were Proteus vulgaris biogroup 3, which included the current type strain of the species $P$. vulgaris (ATCC 29905'), and compared to seven strains of Proteus vulgaris biogroup 2 and nine type strains of other species in the genera Proteus, Providencia and Morganella. By DNA hybridization, these 36 strains were separated into four distinct groups, designated as Proteus genomospecies 3, 4, 5 and 6. DNAs within each separate Proteus genomospecies were $74-99 \%$ related to each other in $60{ }^{\circ} \mathrm{C}$ hybridization reactions with $\leq 4.5 \%$ divergence between related sequences. Proteus genomospecies 3 contained the former $P$. vulgaris type strain and one other strain and was negative in reactions for salicin fermentation, aesculin hydrolysis and deoxyribonuclease, unlike the reactions associated with strains considered as typical $P$. vulgaris which are positive in reactions for salicin, aesculin and DNase. Genomospecies 3 can be distinguished from Proteus genomospecies 4, 5 and 6 because it is negative for Jordan's tartrate. Proteus genomospecies 4, containing five strains, was differentiated from Proteus penneri, genomospecies 3 and 6 and most, but not all, strains of genomospecies 5, by its ability to ferment L-rhamnose. Proteus genomospecies 5 and 6, containing 18 and 11 strains, respectively, could not be separated from each other by traditional biochemical tests, by carbon source utilization tests or SDS-PAGE of whole-cell proteins. In an earlier publication, a request was made to the Judicial Commission that the former type strain of $P$. vulgaris (ATCC 13315) be replaced by $P$. vulgaris biogroup 2 strain ATCC $29905^{\top}$, a strain considered more biochemically typical of $P$. vulgaris strains. This would have the effect of assigning the name $P$. vulgaris to $P$. vulgaris biogroup 2 . Since this request has been acceded to, the name Proteus hauseri is herein proposed for Proteus vulgaris genomospecies 3. Its type strain is ATCC 700826'. Proteus genomospecies 4, 5 and 6 will remain unnamed until better phenotypic differentiation can be accomplished. All Proteus genomospecies were similar in their antimicrobial susceptibility patterns. Nineteen strains were isolated from urine, four from faeces, two from wounds, nine from other human sources and two from animals.

Keywords: Proteus vulgaris, Proteus hauseri 


\section{INTRODUCTION}

Much has been written about the taxonomy of the genus Proteus since the original publication by Hauser (1885) that established the genus. The genus originally had four species: Proteus mirabilis, Proteus rettgeri, Proteus morganii and Proteus vulgaris which is the type species. The genus is a frequent cause of urinary tract infections, but is not usually a nosocomial pathogen. Brenner et al. (1978) showed by DNA-DNA hybridi- zation that $P$. vulgaris was a heterogeneous group with at least three biogroups. In 1982, P. vulgaris biogroup 1 (= genomospecies 1) was named Proteus penneri (Hickman et al., 1982) and was distinguished by its negative reactions for indole production, salicin fermentation and aesculin hydrolysis. The remaining two biogroups were both positive for indole production. However, biogroup 2 (= genomospecies 2 ) was positive for salicin and aesculin and biogroup 3 was negative for salicin and aesculin. The DNA

Table 1. Bacterial strains used in this study

\begin{tabular}{|c|c|c|}
\hline CDC strain no. (additional strain designations) & Location of sender & Source of specimen \\
\hline $\begin{array}{l}\text { PR } 1^{\mathrm{T}}\left(\text { ATCC } 29905^{\mathrm{T}}=\text { CDC 9166-79 }=\text { NCTC } 13145^{\mathrm{T}}\right. \\
\left.=\text { CCUG } 35382^{\mathrm{T}}=\text { CIP } 104989^{\mathrm{T}}\right)\end{array}$ & Denmark & Stool (?) \\
\hline PR 3 & Denmark & Unknown \\
\hline PR 10 & Denmark & Unknown \\
\hline PR 124 (CDC 4138-92) & Unknown & Unknown \\
\hline $\begin{array}{l}1086-80(\text { ATCC } 13315=\text { CDC } 9079-77=\text { CDC } 2130-74 \\
=\text { NCTC } 4175=\text { CCUG } 6327=\text { CIP } 58.60=\text { DSM } 30118)\end{array}$ & Unknown & Unknown \\
\hline $1822-62$ & Massachusetts & Human, unknown \\
\hline 5272-68 (ATCC 27972) & New Jersey & Abdominal wound \\
\hline $1070-73$ & Iowa & Neck lesion \\
\hline $1608-73$ & Delaware & Unknown \\
\hline $2139-74$ & South Dakota & Urine \\
\hline $1425-75$ & Washington & Sputum \\
\hline $0707-76$ & Arizona & Urine \\
\hline $1944-77$ & Canada & Sputum \\
\hline $2049-79$ & Arizona & Urine \\
\hline $1732-80^{\mathrm{T}}\left(\right.$ ATCC $\left.700826^{\mathrm{T}}=\mathrm{CCUG} 35386^{\mathrm{T}}\right)$ & Tennessee & Human, unknown \\
\hline $1392-81$ & Canada & Urine \\
\hline $1393-81$ & Canada & Urine \\
\hline $1394-81$ & Canada & Urine \\
\hline $1395-81$ & Canada & Urine \\
\hline $1396-81$ & Canada & Urine \\
\hline $1397-81$ & Canada & Stool \\
\hline $1398-81$ & Canada & Urine \\
\hline $1399-81$ & Canada & Urine \\
\hline $1400-81$ & Canada & Urine \\
\hline $1401-81$ & Canada & Stool \\
\hline $1402-81$ & Canada & Stool \\
\hline 1404-81 (ATCC $51470=$ CCUG 35385) & Canada & Urine \\
\hline $1405-81$ & Canada & Urine \\
\hline $1406-81$ & Canada & Urine \\
\hline $1407-81$ & Canada & Stool \\
\hline $1408-81$ & Canada & Urine \\
\hline $1409-81$ & Canada & Sputum \\
\hline $1410-81$ & Canada & Urine \\
\hline $1411-81$ & Canada & Urine \\
\hline $4513-89$ & Colorado & Urine \\
\hline $8390-93($ ATCC $51471=87 \mathrm{~B}=$ CCUG 35381) & Great Britain & Urine \\
\hline $8391-93(107 \mathrm{~B})$ & Great Britain & Wound \\
\hline $8385-93($ ATCC $51469=111 \mathrm{~B}=\mathrm{CCUG} 35384)$ & Great Britain & Urine \\
\hline $8386-93$ (119B) & Great Britain & Urine \\
\hline $8388-93(123 B)$ & Great Britain & Urine \\
\hline $8387-93$ (PS 53) & Great Britain & Animal bedding \\
\hline $8389-93$ (PS 36) & Great Britain & Animal bedding \\
\hline GBL 1561 & Wisconsin & Human, unknown \\
\hline
\end{tabular}


Proteus hauseri sp. nov., nom. rev.

Table 2. DNA relatedness of $36 P$. vulgaris biogroup 3 strains

\begin{tabular}{|c|c|c|c|c|c|c|c|c|c|c|c|c|c|c|c|c|c|c|c|c|}
\hline \multirow{3}{*}{$\begin{array}{l}\text { Source of } \\
\text { unlabelled } \\
\text { DNA }\end{array}$} & \multicolumn{20}{|c|}{ Relatedness (\%) to labelled DNA from: } \\
\hline & \multicolumn{4}{|c|}{$\begin{array}{l}\text { P. vulgaris } \\
\text { PR } 1^{\mathrm{T}}\end{array}$} & \multicolumn{4}{|c|}{$\begin{array}{l}\text { P. hauseri } \\
\text { 1732-80 }^{\mathrm{T}}\end{array}$} & \multicolumn{4}{|c|}{$\begin{array}{c}\text { Proteus } \\
\text { genomospecies } 4 \\
8385-93(111 \mathrm{~B})\end{array}$} & \multicolumn{4}{|c|}{$\begin{array}{c}\text { Proteus } \\
\text { genomospecies } 5 \\
1404-81\end{array}$} & \multicolumn{4}{|c|}{$\begin{array}{c}\text { Proteus } \\
\text { genomospecies } 6 \\
8390-93(87 \mathrm{~B})\end{array}$} \\
\hline & $60{ }^{\circ} \mathrm{C}$ & SEM & $D^{*}$ & $75^{\circ} \mathrm{C}$ & $60^{\circ} \mathrm{C}$ & SEM & $D$ & $75^{\circ} \mathrm{C}$ & $60^{\circ} \mathrm{C}$ & SEM & $D$ & $75^{\circ} \mathrm{C}$ & $60{ }^{\circ} \mathrm{C}$ & SEM & $D$ & $75^{\circ} \mathrm{C}$ & $60{ }^{\circ} \mathrm{C}$ & SEM & $D$ & $75^{\circ} \mathrm{C}$ \\
\hline \multicolumn{21}{|c|}{ Proteus vulgaris (biogroup 2) } \\
\hline $\begin{array}{l}\text { PR } 1^{\mathrm{T}}(\mathrm{ATCC} \\
\left.29905^{\mathrm{T}}\right)\end{array}$ & 100 & $0 \cdot 0$ & 100 & & 57 & $3 \cdot 5$ & & 15 & 62 & $3 \cdot 5$ & $3 \cdot 5$ & 39 & 70 & 1.5 & & 39 & 64 & $3 \cdot 5$ & $7 \cdot 0$ & 40 \\
\hline PR 3 & 100 & 0 & $0 \cdot 0$ & 98 & & & & & & & & & & & & & & & & \\
\hline $1608-73$ & 99 & 0.9 & $0 \cdot 0$ & 97 & & & & & & & & & & & & & & & & \\
\hline PR 10 & 96 & $2 \cdot 1$ & $0 \cdot 0$ & 100 & & & & & & & & & & & & & & & & \\
\hline 1944-77 & 91 & $2 \cdot 8$ & $1 \cdot 0$ & 78 & & & & & & & & & & & & & & & & \\
\hline $1425-75$ & 80 & $2 \cdot 1$ & $0 \cdot 0$ & 78 & & & & & & & & & & & & & & & & \\
\hline 2049-79 & 64 & $2 \cdot 2$ & $0 \cdot 0$ & 70 & & & & & & & & & & & & & & & & \\
\hline \multicolumn{21}{|l|}{ Proteus hauseri } \\
\hline $\begin{array}{l}1732-80^{\mathrm{T}} \\
\left(\mathrm{ATCC} 700826^{\mathrm{T}}\right)\end{array}$ & & & & & 92 & 3.9 & $0 \cdot 5$ & 100 & & & & & & & & & & & & \\
\hline $\begin{array}{l}\text { 1086-80 } \\
\text { (ATCC 13315) }\end{array}$ & 44 & $1 \cdot 0$ & $11 \cdot 0$ & 13 & 100 & & $0 \cdot 0$ & 100 & & & & & 38 & $0 \cdot 0$ & $9 \cdot 5$ & & & & & \\
\hline Proteus genomospecies 4 & & & & & & & & & & & & & & & & & & & & \\
\hline $\begin{array}{l}\text { 8385-93 } \\
\text { (ATCC 51469) }\end{array}$ & & & & & 55 & 8.5 & & & 100 & - & $0 \cdot 0$ & 100 & 63 & $2 \cdot 1$ & $6 \cdot 5$ & 30 & 74 & 1.5 & $6 \cdot 5$ & 48 \\
\hline $1070-73$ & 68 & 0 & & 35 & 68 & $3 \cdot 5$ & & 19 & 97 & $3 \cdot 0$ & $0 \cdot 0$ & 93 & 72 & $3 \cdot 0$ & $5 \cdot 5$ & 45 & 71 & $1 \cdot 5$ & $6 \cdot 5$ & 45 \\
\hline PR 124 & & & & & 42 & $2 \cdot 0$ & & & 94 & $4 \cdot 0$ & $0 \cdot 0$ & 94 & 68 & $3 \cdot 5$ & $6 \cdot 0$ & 34 & & & & \\
\hline $8386-93$ & & & & & 61 & $6 \cdot 5$ & & & 83 & 0 & $0 \cdot 0$ & 87 & 71 & 2.5 & $5 \cdot 5$ & 38 & & & & \\
\hline $8387-93$ & & & & & 50 & $4 \cdot 5$ & & & 82 & $4 \cdot 6$ & $3 \cdot 0$ & 80 & 52 & 1.5 & $9 \cdot 0$ & 23 & & & & \\
\hline Proteus genomospecies 5 & & & & & & & & & & & & & & & & & & & & \\
\hline $\begin{array}{l}1404-81 \\
(\text { ATCC 51470) }\end{array}$ & & & & & 42 & $2 \cdot 0$ & & & 65 & $4 \cdot 5$ & $6 \cdot 5$ & 38 & 100 & - & $0 \cdot 0$ & 100 & 72 & $1 \cdot 0$ & $4 \cdot 5$ & 58 \\
\hline $1394-81$ & & & & & 44 & $2 \cdot 0$ & & & & & & & 90 & $4 \cdot 5$ & $0 \cdot 5$ & 87 & & & & \\
\hline $1408-81$ & & & & & 6 & $4 \cdot 0$ & & & & & & & 89 & $1 \cdot 0$ & $2 \cdot 5$ & 83 & & & & \\
\hline $1406-81$ & & & & & 28 & $1 \cdot 0$ & & & 62 & $5 \cdot 1$ & $5 \cdot 5$ & 37 & 89 & $4 \cdot 2$ & $3 \cdot 0$ & 64 & & & & \\
\hline $1411-81$ & & & & & 59 & $8 \cdot 0$ & & & & & & & 87 & $1 \cdot 0$ & $2 \cdot 0$ & 83 & & & & \\
\hline $1407-81$ & & & & & 17 & 1.0 & & & 64 & $5 \cdot 2$ & $4 \cdot 5$ & 46 & 87 & 0 & $3 \cdot 5$ & 65 & & & & \\
\hline $8388-93$ & & & & & 47 & $2 \cdot 0$ & & & 57 & 0.5 & $5 \cdot 0$ & 43 & 87 & 0.5 & $4 \cdot 0$ & 62 & & & & \\
\hline $2139-74$ & 60 & $0 \cdot 3$ & $7 \cdot 0$ & 28 & 43 & $1 \cdot 0$ & & 17 & 60 & $4 \cdot 0$ & $5 \cdot 0$ & 50 & 86 & $2 \cdot 3$ & $2 \cdot 0$ & 77 & & & & \\
\hline $1401-81$ & & & & & 49 & $5 \cdot 0$ & & & & & & & 85 & $2 \cdot 0$ & $0 \cdot 5$ & 83 & & & & \\
\hline $1410-81$ & 54 & $1 \cdot 0$ & & 30 & 21 & $1 \cdot 0$ & & & 56 & $1 \cdot 0$ & $5 \cdot 0$ & 47 & 85 & $2 \cdot 0$ & $3 \cdot 0$ & 68 & & & & \\
\hline $1822-62$ & & & & & 66 & 1.5 & & & 69 & $3 \cdot 3$ & $4 \cdot 5$ & 35 & 85 & $4 \cdot 2$ & $3 \cdot 5$ & 61 & & & & \\
\hline $1409-81$ & & & & & 26 & 1.5 & & & 58 & $4 \cdot 0$ & $8 \cdot 5$ & 37 & 82 & $3 \cdot 6$ & $4 \cdot 0$ & 58 & & & & \\
\hline $1392-81$ & & & & & 35 & 1.5 & & 15 & 60 & $2 \cdot 5$ & $5 \cdot 5$ & 48 & 81 & $3 \cdot 2$ & $3 \cdot 0$ & 70 & & & & \\
\hline 0707-76 & 50 & $0 \cdot 7$ & $6 \cdot 5$ & 25 & 34 & $4 \cdot 0$ & & 14 & 59 & $3 \cdot 0$ & $5 \cdot 0$ & 49 & 80 & $7 \cdot 0$ & $1 \cdot 5$ & 66 & & & & \\
\hline $1402-81$ & & & & & 46 & 1.0 & & & 51 & $3 \cdot 0$ & 6.0 & 43 & 80 & $3 \cdot 4$ & $2 \cdot 0$ & 72 & & & & \\
\hline $8389-93$ & & & & & 63 & 1.5 & & & 57 & 1.0 & 6.0 & 38 & 80 & $3 \cdot 5$ & $3 \cdot 5$ & 72 & & & & \\
\hline $1399-81$ & & & & & 46 & $7 \cdot 5$ & & & 54 & $5 \cdot 0$ & 6.0 & 46 & 77 & $3 \cdot 0$ & $3 \cdot 0$ & 63 & & & & \\
\hline $1400-81$ & & & & & 19 & $1 \cdot 0$ & & & 44 & $3 \cdot 5$ & $6 \cdot 5$ & 32 & 74 & $3 \cdot 4$ & $2 \cdot 5$ & 62 & & & & \\
\hline Proteus genomospecies 6 & & & & & & & & & & & & & & & & & & & & \\
\hline $\begin{array}{l}8390-93 \\
(\text { ATCC 51471) }\end{array}$ & & & & & 61 & $2 \cdot 5$ & & & 47 & $2 \cdot 0$ & $6 \cdot 0$ & 35 & 73 & $2 \cdot 5$ & $6 \cdot 0$ & 50 & 100 & - & $0 \cdot 0$ & 100 \\
\hline GBL 1561 & & & & & 60 & $2 \cdot 0$ & & & 62 & $3 \cdot 5$ & $5 \cdot 5$ & 35 & 70 & $4 \cdot 8$ & $6 \cdot 5$ & 35 & 99 & $1 \cdot 0$ & $1 \cdot 5$ & 93 \\
\hline $5272-68$ & & & & & 56 & $4 \cdot 0$ & & & 60 & $4 \cdot 5$ & $4 \cdot 5$ & 37 & 73 & $4 \cdot 5$ & $3 \cdot 5$ & 48 & 98 & $2 \cdot 5$ & $0 \cdot 5$ & 90 \\
\hline $4513-89$ & & & & & 41 & $2 \cdot 0$ & & & 47 & $3 \cdot 5$ & $6 \cdot 0$ & 38 & 68 & $4 \cdot 0$ & $8 \cdot 5$ & 35 & 95 & $2 \cdot 0$ & $2 \cdot 5$ & 87 \\
\hline $1396-81$ & & & & & 48 & 1.5 & & & 44 & $5 \cdot 0$ & $6 \cdot 5$ & 36 & 68 & $2 \cdot 7$ & $4 \cdot 5$ & 42 & 94 & $1 \cdot 5$ & $1 \cdot 5$ & 94 \\
\hline $1393-81$ & & & & & & & & & 59 & $0 \cdot 5$ & $6 \cdot 5$ & 40 & 75 & $3 \cdot 0$ & $4 \cdot 0$ & 52 & 94 & $1 \cdot 0$ & $2 \cdot 0$ & 86 \\
\hline $1398-81$ & & & & & 22 & 0.5 & & 8 & 54 & $0 \cdot 5$ & $7 \cdot 0$ & 38 & 71 & $3 \cdot 8$ & $5 \cdot 0$ & 40 & 92 & $1 \cdot 5$ & $2 \cdot 0$ & 85 \\
\hline $1405-81$ & & & & & 46 & 0 & & & 45 & $4 \cdot 0$ & 6.5 & 35 & 66 & $5 \cdot 5$ & $4 \cdot 5$ & 28 & 92 & $2 \cdot 5$ & $2 \cdot 0$ & 86 \\
\hline $1395-81$ & & & & & 33 & $2 \cdot 0$ & & & 29 & $3 \cdot 5$ & $8 \cdot 0$ & 20 & 61 & $3 \cdot 3$ & $7 \cdot 5$ & 30 & 91 & $2 \cdot 5$ & $4 \cdot 5$ & 82 \\
\hline $8391-93$ & & & & & 59 & $2 \cdot 5$ & & & 54 & $3 \cdot 0$ & $5 \cdot 0$ & 40 & 78 & $3 \cdot 1$ & $4 \cdot 5$ & 42 & 90 & $6 \cdot 0$ & $2 \cdot 0$ & 82 \\
\hline $1397-81$ & & & & & 51 & 0.5 & & & 53 & 0.5 & $6 \cdot 0$ & 37 & 73 & 2.5 & $4 \cdot 0$ & 47 & 88 & 0 & 1.5 & 84 \\
\hline Proteus penneri $1808-73^{\mathrm{T}}$ & 54 & 0.6 & $7 \cdot 5$ & 30 & 60 & 1.5 & & & 67 & 8.0 & $2 \cdot 5$ & 41 & 70 & $4 \cdot 2$ & $6 \cdot 0$ & 37 & 71 & $4 \cdot 5$ & $6 \cdot 5$ & 49 \\
\hline Proteus mirabilis $\mathrm{PR} 14^{\mathrm{T}}$ & & & & & 50 & $3 \cdot 0$ & & & & & & & 46 & $4 \cdot 5$ & & & & & & \\
\hline $\begin{array}{l}\text { Proteus myxofaciens } \\
\text { ATCC } 19692^{\mathrm{T}}\end{array}$ & & & & & 41 & 0 & & & & & & & 38 & $3 \cdot 0$ & & & & & & \\
\hline $\begin{array}{l}\text { Providencia rustigianii } \\
132-68^{\mathrm{T}}\end{array}$ & & & & & 25 & 1.5 & & & & & & & 19 & $1 \cdot 0$ & & & & & & \\
\hline $\begin{array}{l}\text { Providencia alcalifaciens } \\
3370-67^{\mathrm{T}}\end{array}$ & & & & & 20 & 0 & & & & & & & 18 & $2 \cdot 0$ & & & & & & \\
\hline $\begin{array}{l}\text { Providencia heimbachae } \\
\text { ATCC } 35613^{\mathrm{T}}\end{array}$ & & & & & & & & & & & & & 17 & $1 \cdot 0$ & & 2 & & & & \\
\hline $\begin{array}{l}\text { Providencia rettgeri } \\
1163^{\mathrm{T}}\end{array}$ & & & & & 17 & $2 \cdot 0$ & & & & & & & 17 & $1 \cdot 0$ & & & & & & \\
\hline $\begin{array}{l}\text { Morganella morganii } \\
\text { subsp. morganii } \\
4567-84^{\mathrm{T}}\end{array}$ & & & & & 24 & 0 & & & & & & & 16 & $2 \cdot 0$ & & & & & & \\
\hline $\begin{array}{l}\text { Providencia stuartii } \\
2896-68^{\mathrm{T}}\end{array}$ & & & & & 16 & 0.5 & & & & & & & 14 & 0.5 & & & & & & \\
\hline
\end{tabular}

* $D$, Divergence $(\%)$. 
hybridization reference strain of $P$. vulgaris $\left(\mathrm{PR} 1^{\mathrm{T}}=\right.$ ATCC $29905^{\mathrm{T}}$ ) genetically belongs in and has the phenotypic characteristics of biogroup 2 in that it is positive in tests for indole, salicin and aesculin. In a previous publication (Brenner, 1995) this strain was proposed as the neotype strain of $P$. vulgaris. The former type strain of $P$. vulgaris, however, belongs to biogroup 3 by DNA-DNA hybridization and is very uncharacteristic of biogroup 2 in its biochemical reactions. It belongs to biogroup 3 phenotypically because it is positive for indole production and is negative for salicin and aesculin. In taxonomic studies, McKell \& Jones (1976) reported that this strain was clearly atypical and fell outside both $P$. vulgaris subclusters. In studies by Costas et al. (1993), utilizing SDS-PAGE protein patterns, the type strain belonged to a separate small subcluster. In this report, we further define biogroup 3.

\section{METHODS}

Bacterial strains. Included in the study were 7 strains of Proteus vulgaris biogroup 2, 36 strains of Proteus vulgaris biogroup 3 and 9 type and reference hybridization strains representing most of the species in the genera Proteus, Providencia and Morganella (Table 1). All the strains were maintained in defibrinated sheep blood and stored frozen at $-70{ }^{\circ} \mathrm{C}$. They were passed twice on Trypticase Soy Agar with $5 \%$ sheep blood (TSA II: Becton Dickinson) before use.

Media and biochemical tests. The biochemical tests were performed on conventional media as previously described (Farmer et al., 1980), with some modifications by Hickman $\&$ Farmer (1978). Incubations were at $35^{\circ} \mathrm{C}$ and test results were read at $24 \mathrm{~h}, 48 \mathrm{~h}$ and $7 \mathrm{~d}$, unless otherwise noted. Commercial media were used whenever possible. Carbon source utilization tests were done at the Institut Pasteur using Biotype 100 strips (bioMérieux) that contained 99 pure carbon sources. The strips were inoculated using Biotype medium 1, according to the manufacturer's instructions.

Antimicrobial susceptibilities. MIC tests were performed by the broth microdilution method as described by the National Committee for Clinical Laboratory Standards (1997) using Mueller-Hinton broth (BDMS). Quality control organisms included Escherichia coli ATCC 25922, Enterococcus faecalis ATCC 29212 and Pseudomonas aeruginosa ATCC 27853.

DNA methods. The preparation, isolation and purification of labelled and unlabelled DNA, the method used for DNA reassociation and the method used to separate single- and double-stranded DNA on hydroxyapatite have been described by Brenner et al. (1982, 1993). DNAs were labelled enzymically in vitro with $\left[{ }^{32} \mathrm{P}\right] \mathrm{dCTP}$ using a nick translation reagent kit (Bethesda Research Laboratories) as directed by the manufacturer.

Electrophoretic protein patterns. The preparation of protein samples, electrophoresis, staining and scanning of gels as well as the analysis and computation of similarity of patterns have been described by Costas et al. (1993).

\section{RESULTS AND DISCUSSION}

This study determined that biogroup 3 is actually composed of four distinct DNA groups that were designated Proteus genomospecies 3, 4, 5 and 6 (Table 2). The former P. vulgaris type strain (ATCC 13315) and only one other strain belong to Proteus genomospecies 3 . Because of the association of the specific epithet $P$. vulgaris with the former type strain ATCC 13315 (Buchanan et al., 1963), which is not typical of the majority of strains ascribed to this species, a Request for an Opinion was made to the Judicial Commission of the International Committee on Systematic Bacteriology for resolution of this problem (Brenner et al., 1995). On the basis of DNA hybridization, Brenner et al. (1995) recommended that biogroup 2, which is commonly recognized in clinical laboratories, retain the name Proteus vulgaris and that the DNA hybridization reference strain PR $1^{\mathrm{T}}$ (ATCC $29905^{\mathrm{T}}$ ) be designated as the neotype strain of the species. P. vulgaris strain PR $1^{\mathrm{T}}$ has the characteristic biochemical reactions associated with biogroup 2 . In 1999 that request was granted (Trüper, 1999).

Table 3 presents the reactions of three named species and three unnamed genomospecies of Proteus. Proteus genomospecies 4 can be separated phenotypically from Proteus genomospecies 3 by its positive tests for Lrhamnose fermentation, lipase production, Jordan's tartrate and DNase. Proteus genomospecies 4 can be separated from Proteus genomospecies 6 by its positive reaction for L-rhamnose, but cannot be differentiated from Proteus genomospecies 5 because there are three L-rhamnose-positive strains in the genomospecies 5 group. There are no definitive criteria for the phenotypic separation of Proteus genomospecies 4 and 5 or of genomospecies 5 and 6 .

Of the 11 isolates of Proteus genomospecies 6 for which DNA relatedness was determined, 10 were negative in tests for salicin and aesculin. One strain (8391-93) with high reassociation constants was positive for salicin and aesculin, which would place it in biogroup 2. Repeat hybridization of this single strain against both 8390-93 (candidate type strain for Proteus genomospecies 6) and PR $1^{\mathrm{T}}$ (ATCC $29905^{\mathrm{T}}$, neotype strain of $P$. vulgaris) yielded the same results, confirming its inclusion in Proteus genomospecies 6. However, this strain was negative in the test for DNase, unlike the strains of biogroup 2. With respect to the abnormally low relatedness between $P$. hauseri and one or two strains in genomospecies 5 and 6 , there is no doubt as to which genomospecies these strains belong. Hence, these strains were not rehybridized.

When the 36 strains of biogroup 3 were tested in the Biotype 100 carbon source utilization strips, there were insufficient differences to allow differentiation of all four Proteus genomospecies. The exception was the utilization of L-rhamnose by all of the Proteus genomospecies 4 strains which correlated with the reactions obtained with Andrade's fermentation medium containing $0.5 \%$ L-rhamnose. Differentiation using Lrhamnose was complicated by the fact that three isolates of Proteus genomospecies 5 were L-rhamnosepositive using Andrade's medium and one isolate was L-rhamnose-positive in the carbon source strip. 
Table 3. Biochemical characteristics of Proteus penneri, Proteus vulgaris, Proteus hauseri and Proteus genomospecies 4, 5 and 6

All taxa are positive in reactions for phenylalanine deaminase, tyrosine utilization and the production of acid from D-glucose and D-xylose. All taxa are negative in reactions for Voges-Proskauer, lysine and ornithine decarboxylase, arginine dihydrolase, malonate utilization, production of yellow pigment at $25^{\circ} \mathrm{C}$ and acid production from D-adonitol, L-arabinose, D-arabitol, cellobiose, dulcitol, erythritol, myo-inositol, D-mannitol, D-mannose, melibiose, D-sorbitol and mucate. Boxed areas represent biochemical characteristics (percentage positive at $48 \mathrm{~h}$ ) useful in differentiating Proteus species and genomospecies.

\begin{tabular}{|c|c|c|c|c|c|c|}
\hline Test & $\begin{array}{c}\text { Proteus } \\
\text { penneri }(54) *\end{array}$ & $\begin{array}{c}\text { Proteus } \\
\text { vulgaris (7) }\end{array}$ & $\begin{array}{c}\text { Proteus } \\
\text { hauseri (2) }\end{array}$ & $\begin{array}{l}\text { Proteus genomo- } \\
\text { species } 4(5)\end{array}$ & $\begin{array}{c}\text { Proteus genomo- } \\
\text { species } 5 \text { (18) }\end{array}$ & $\begin{array}{c}\text { Proteus genomo- } \\
\text { species } 6(11)\end{array}$ \\
\hline Indole production & 0 & 100 & 100 & 100 & 100 & 100 \\
\hline Methyl red & 100 & 86 & 100 & 100 & 100 & 100 \\
\hline Citrate (Simmons) & 4 & 29 & 0 & 0 & 0 & 0 \\
\hline $\begin{array}{l}\text { Hydrogen sulfide } \\
\text { (on TSI Agar) }\end{array}$ & 32 & 57 & $50(-\dagger)$ & 80 & 94 & 73 \\
\hline Urea (Christensen) & 98 & 86 & 100 & 100 & 100 & 100 \\
\hline Motility & 89 & 57 & 100 & 100 & 94 & 100 \\
\hline Gelatin hydrolysis $\left(22^{\circ} \mathrm{C}\right)$ & 56 & 57 & 100 & 100 & 100 & 100 \\
\hline Growth in $\mathrm{KCN}$ & 98 & 100 & 100 & 100 & 100 & 90 \\
\hline \multicolumn{7}{|l|}{ D-Glucose } \\
\hline Gas production & 46 & 86 & 0 & 80 & 83 & 91 \\
\hline \multicolumn{7}{|l|}{ Acid production from: } \\
\hline D-Galactose & 96 & 83 & 100 & 100 & 100 & 100 \\
\hline Glycerol & 40 & 29 & 0 & 0 & 0 & 0 \\
\hline Lactose & 9 & 0 & 0 & 0 & 0 & 0 \\
\hline Maltose & 96 & 100 & 100 & 100 & 100 & 100 \\
\hline$\alpha$-Methyl-D-glucoside & 81 & 86 & $50(-)$ & 60 & 0 & 10 \\
\hline Raffinose & 9 & 0 & 0 & 0 & 0 & 0 \\
\hline L-Rhamnose & 0 & 0 & 0 & 100 & 17 & 0 \\
\hline Salicin & 0 & 100 & 0 & 0 & 0 & 9 \\
\hline Sucrose & 96 & 100 & 100 & 100 & 100 & 100 \\
\hline Trehalose & 62 & 0 & 0 & 20 & 12 & 20 \\
\hline Tartrate (Jordan) & 89 & 14 & 0 & 100 & 100 & 100 \\
\hline Aesculin hydrolysis & 0 & 100 & 0 & 0 & 0 & 9 \\
\hline Acetate utilization & 12 & 14 & 0 & 0 & 12 & 18 \\
\hline Lipase (corn oil) & 35 & 14 & 0 & 100 & 100 & 90 \\
\hline DNase $\left(25^{\circ} \mathrm{C}\right)$ & 12 & 100 & 0 & 100 & 100 & 55 \\
\hline $\mathrm{NO}_{3}^{-} \rightarrow \mathrm{NO}_{2}^{-}$ & 80 & 57 & 100 & 100 & 100 & 91 \\
\hline ONPG & 10 & 0 & 0 & 0 & 0 & 0 \\
\hline Hydrogen sulfide (PIA) & 47 & 57 & $50(-)$ & 80 & 94 & 80 \\
\hline
\end{tabular}

* Number of strains in database.

$\dagger$ Reaction of type strain ATCC $700826^{\mathrm{T}}$ (CDC 1732-80T).

When the strains of biogroup 3 (representing Proteus genomospecies 3, 4, 5 and 6), in addition to those of the previous study, were included in the analysis of Costas et al. (1993), the original differentiation into clusters $3 a$ and $3 \mathrm{~b}$ was no longer apparent. A greater degree of heterogeneity was evident in the protein patterns of the biogroup 3 strains than in the other taxa examined, but there was no correlation with the four groups recognized by DNA-DNA hybridization.

We propose that Proteus genomospecies 3 become known as Proteus hauseri. Proteus genomospecies 3 contains only the original type strain of $P$. vulgaris and one other strain. We propose ATCC $700826^{\mathrm{T}}$ (CDC
$\left.1732-80^{\mathrm{T}}\right)$ as the type strain to avoid the possible confusion if ATCC 13315 (former type strain of $P$. vulgaris) were proposed as the $P$. hauseri type strain.

Proteus genomospecies 4, 5 and 6 have not been formally named since they cannot be phenotypically separated with certainty.

The MICs of 14 antimicrobial agents for isolates from P. hauseri and Proteus genomospecies 4, 5 and 6 are shown in Table 4. They were similar in their antimicrobial susceptibility patterns, being susceptible to amikacin, aztreonam, ceftazidime, ciprofloxacin, gentamicin, imipenem, mezlocillin, tobramycin and trimethoprim/sulfamethoxazole. They were resistant to 
Table 4. Antimicrobial susceptibilities $\left(\mu \mathrm{g} \mathrm{ml}^{-1}\right)$ of Proteus hauseri and Proteus genomospecies 4, 5 and 6

\begin{tabular}{|c|c|c|c|c|}
\hline Antimicrobial & $\begin{array}{l}\text { Proteus } \\
\text { hauseri }\end{array}$ & $\begin{array}{c}\text { Proteus } \\
\text { genomospecies } 4\end{array}$ & $\begin{array}{c}\text { Proteus } \\
\text { genomospecies } 5\end{array}$ & $\begin{array}{c}\text { Proteus } \\
\text { genomospecies } 6\end{array}$ \\
\hline Ampicillin & $2-128$ & $>256$ & $\geqslant 32$ & $>256$ \\
\hline Mezlocillin & $\leqslant 8$ & $\leqslant 8$ & $\leqslant 8-16$ & $\leqslant 4->128$ \\
\hline Aztreonam & $\leqslant 1-4$ & $\leqslant 1$ & $\leqslant 1$ & $\leqslant 1$ \\
\hline Imipenem & $\leqslant 0 \cdot 25-1$ & $2-16$ & $0 \cdot 5-4$ & $\leqslant 0 \cdot 25-4$ \\
\hline Tetracycline & $\leqslant 0 \cdot 5$ & $\geqslant 16$ & $1->32$ & $1->32$ \\
\hline Cefazolin & $\leqslant 0 \cdot 5-\geqslant 32$ & $>32$ & $>32$ & $>32$ \\
\hline Cefoxitin & $\leqslant 2$ & 4 & $2-16$ & $2-4$ \\
\hline Cefotaxime & $\leqslant 4$ & $\leqslant 4$ & $\leqslant 8$ & $\leqslant 4$ \\
\hline Ceftazidime & $\leqslant 2$ & $\leqslant 0 \cdot 5$ & $\leqslant 2$ & $\leqslant 1$ \\
\hline Trimethoprim/sulfamethoxazole $(1: 19)$ & $\leqslant 0 \cdot 12$ & $\leqslant 0 \cdot 25$ & $\leqslant 0 \cdot 12-8$ & $\leqslant 0 \cdot 12->16$ \\
\hline Ciprofloxacin & $\leqslant 0 \cdot 06$ & $\leqslant 0.06$ & $\leqslant 0 \cdot 06$ & $\leqslant 0.06$ \\
\hline Amikacin & $\leqslant 1$ & $\leqslant 8$ & $\leqslant 16$ & $\leqslant 8$ \\
\hline Gentamicin & $\leqslant 0 \cdot 25$ & $\leqslant 4$ & $1-8$ & $\leqslant 4$ \\
\hline Tobramycin & $\leqslant 0 \cdot 25$ & $\leqslant 2$ & $0 \cdot 5-8$ & $\leqslant 2$ \\
\hline
\end{tabular}

ampicillin and cefazolin and $63 \%$ were resistant to tetracycline. With cefotaxime, most strains were resistant by MIC tests. There were no distinct patterns of resistance that could be discerned among these four groups. The small numbers of strains in each group preclude us from drawing any conclusions about what may be useful differences in antibiograms among the groups. Caution must be exercised in translating the categorical interpretation of the broth dilution results to disk diffusion as discrepancies between the interpretative categories of two test methods have been noted for other Proteus and Morganella strains and some cephalosporins (Biedenbach \& Jones, 1994).

\section{Description of Proteus hauseri sp. nov., nom. rev.}

Proteus hauseri (hau'ser.i. N.L. gen. n. hauseri to honour Gustav Hauser, the German microbiologist, who proposed the genus Proteus in 1885).

Corresponds to Proteus genomospecies 3. Strains are Gram-negative, oxidase-negative, fermentative, nonpigmented rods with the general characteristics of the family Enterobacteriaceae and of the genus Proteus (Table 3). The strains are positive for indole production and negative for aesculin hydrolysis and salicin fermentation. Biochemically these strains are similar to those commonly identified as Proteus vulgaris. They can be separated from the other Proteus genomospecies using L-rhamnose fermentation, DNase, lipase production and Jordan's tartrate utilization. Full biochemical reactions are given in Table 3 (useful biochemical reactions for the differentiation of the named species and unnamed genomospecies are boxed). Pathogenicity in humans and animals is undetermined. $P$. hauseri contains two strains from unknown sources. The type strain is ATCC $700826^{\mathrm{T}}$ $\left(\mathrm{CDC} 1732-80^{\mathrm{T}}\right)$.

\section{Description of Proteus genomospecies 4}

Proteus genomospecies 4 is generally separated from the other Proteus species because it ferments Lrhamnose. However, the strains can be separated from Proteus genomospecies 3 by positive reactions for DNase, lipase and Jordan's tartrate. Differentiation from Proteus genomospecies 5 may be difficult in the absence of a negative test for L-rhamnose. Two strains of this organism were isolated from human urine and one each from a neck wound and animal bedding. The source of one strain is unknown. Pathogenicity for humans and animals is undetermined. The candidate type strain is ATCC $51469^{\mathrm{T}}\left(=\mathrm{CDC} 8385-93^{\mathrm{T}}=\right.$ Hawkey 111B), isolated from a mid-stream urine sample (Bristol, Avon, UK).

\section{Description of Proteus genomospecies 5}

Positive for the production of lipase, DNase and utilization of Jordan's tartrate. The 18 strains of this organism were isolated from human urine (12), stool (3), sputum (1), animal bedding (1) and unknown (1). Pathogenicity for humans and animals is undetermined. The candidate type strain is ATCC $51470^{\mathrm{T}}$ (= CDC $\left.1404-81^{\mathrm{T}}\right)$, isolated from a mid-stream urine sample (Toronto, Ontario, Canada).

\section{Description of Proteus genomospecies 6}

Biochemically similar to Proteus genomospecies 5 when it is tested against the substrates described herein. It is L-rhamnose-negative, but one strain is positive in tests for salicin and aesculin which would place it in biogroup 2. Unlike biogroup 2, however, it is DNasenegative. The 11 strains of this organism were isolated from human urine (7), wound (2), stool (1) and one 
strain from an unknown human source. Pathogenicity for humans and animals is undetermined. The candidate type strain is ATCC $51471^{\mathrm{T}}\left(=\mathrm{CDC} 8390-93^{\mathrm{T}}\right.$ $=$ Hawkey 87B) which was isolated from a mid-stream urine sample of a patient in Bristol Children's Hospital, Bristol, Avon, UK.

\section{ACKNOWLEDGEMENTS}

We thank Brian Plikaytis and Kathleen Shutt for providing the statistical data.

\section{REFERENCES}

Biedenbach, D. J. \& Jones, R. N. (1994). Predictive accuracy of disk diffusion test for Proteus vulgaris and Providencia species against five newer orally administered cephalosporins, cefdinir, cefetamet, cefprozil, cefuroxime and loracarbef, J Clin Microbiol 32, 559-562.

Brenner, D. J., Farmer, J. J., III, Fanning, G. R., Steigerwalt, A. G., Klykken, P., Wathen, H. G., Hickman, F. W. \& Ewing, W. H. (1978). Deoxyribonucleic acid relatedness of Proteus and Providencia species, Int J Syst Bacteriol 28, 269-282.

Brenner, D. J., McWhorter, A. C., Leete-Knutson, J. K. \& Steigerwalt, A. G. (1982). Escherichia vulneris: a new species of Enterobacteriaceae associated with human wounds, J Clin Microbiol 15, 1133-1140.

Brenner, D. J., Grimont, P. A. D., Steigerwalt, A. G., Fanning, G. R., Ageron, E. \& Riddle, C. F. (1993). Classification of citrobacteria by DNA hybridization: designation of Citrobacter farmeri sp. nov., Citrobacter youngae sp. nov., Citrobacter braakii sp. nov., Citrobacter werkmanii sp. nov., Citrobacter sedlakii sp. nov., and three unnamed Citrobacter genomospecies, Int J Syst Bacteriol 43, 645-658.

Brenner, D. J., Hickman-Brenner, F. W., Holmes, B., Hawkey, P. M., Penner, J. L., Grimont, P. A. D. \& O'Hara, C. M. (1995). Replacement of NCTC 4175, the current type strain of Proteus vulgaris, with ATCC 29905: request for an opinion, Int J Syst Bacteriol 45, 870-871.

Buchanan, R. E., Seeliger, H. P. R. \& Clark, W. A. (1963). Opinion 26. Designation of neotype strains (cultures) of type species of the bacterial genera Salmonella, Shigella, Arizona, Escherichia, Citrobacter and Proteus of the family Enterobacteriaceae, Int Bull Bacteriol Nomencl Taxon 13, 35-36.

Costas, M., Holmes, B., Frith, K. A., Riddle, C. \& Hawkey, P. M. (1993). Identification and typing of Proteus penneri and Proteus vulgaris biogroups 2 and 3 , from clinical sources, by computerized analysis of electrophoretic protein patterns, $J$ Appl Bacteriol 75, 489-498.

Farmer, J. J., III, Asbury, M. A., Hickman, F. W., Brenner, D. J. \& the Enterobacteriaceae Study Group (1980). Enterobacter sakazakii: a new species of 'Enterobacteriaceae' isolated from clinical specimens. Int J Syst Bacteriol 30, 569-584.

Hauser, G. (1885). Uber Fäulnissbacterien und deren Beziehungen zur Septicämie. In Ein Beitrag zur Morphologie der Spaltpilze. p. 12. Leipzig: Vogel.

Hickman, F. W. \& Farmer, J. J., III (1978). Salmonella typhi: identification, antibiograms, serology, and bacteriophage typing, Am J Med Technol 44, 1149-1159.

Hickman, F. W., Steigerwalt, A. G., Farmer, J. J., III \& Brenner, D. J. (1982). Identification of Proteus penneri sp. nov., formerly known as Proteus vulgaris indole negative or as Proteus vulgaris biogroup 1, J Clin Microbiol 15, 1097-1102.

McKell, J. \& Jones, D. (1976). A numerical taxonomic study of Proteus-Providencia bacteria, J Appl Bacteriol 41, 133-161.

National Committee for Clinical Laboratory Standards (1997). Standard methods for dilution antimicrobial susceptibility tests for bacteria that grow aerobically. Approved standard M7-A4. Wayne, PA: National Committee for Clinical Laboratory Standards.

Trüper, H. G. (1999). Replacement of strain NCTC 4175, since 1963 the neotype strain of Proteus vulgaris, with strain ATCC 29905 - Opinion 70, Int J Syst Bacteriol 49, 1949. 